\title{
Charakterystyka i potencjał innowacyjny gospodarstw typu rodzinnego w Polsce
}

\section{Wstęp}

W latach 2003-2004 prowadzono badania w ramach pracy nad doktoratem pierwszego $\mathrm{z}$ autorów pt. „Zainteresowanie rozwojem w polskich gospodarstwach rolnych (chłopskich) i ich przyszłość w europejskim modelu rozwojowym: ujęcie etnograficzno-rolnicze i społeczno-ekonomiczne". Jakościowa analiza polskich typów gospodarstw rolnych przeprowadzona ma być $\mathrm{w}$ czasie trzech, sukcesywnie po sobie następujących okresach. W 2003 r. pierwsze badania zostały przeprowadzone w 20 małych, zróżnicowanych gospodarstwach rolnych (uprawy polowe i bydło). Połowa $z$ nich usytuowana była w okolicach Białegostoku, na Podlasiu. W drugiej połowie badania miały miejsce w Małopolsce, głównie w gminie Raciechowice. W czasie pierwszej tury badań przeprowadzonych metodą wywiadu według kwestionariusza badawczego przyjęto dwie hipotezy. Pierwsza z nich zakładała, że stając w obliczu kryzysu ekonomicznego, rolnicy mogą rozwijać specyficzne strategie adaptacyjne. W badaniu starano się zrozumieć i opisać te strategie. Jako drugą hipotezę wysunięto przypuszczenie, że brak wpływów finansowych przyczynia się do redukcji zakupowanych przez gospodarstwa nakładów środków chemicznych i pracy mechanicznej, a ta sytuacja może powodować, iż wprowadzane są alternatywne techniki gospodarowania, które przyczyniają się do utrzymania równowagi między działaniami rolniczymi a ochroną naturalnych zasobów środowiska. W badanych dwudziestu gospodarstwach zadawano pytania dotyczące członków rodziny pracujących $\mathrm{w}$ gospodarstwie (stale i okresowo), organizacji pracy (jej

\footnotetext{
'Inż., doktorant w Département d'Economie Rurale et Gestion, ENSA Rennes, Francja, e-mail: catherine.darrot@wanadoo.fr

${ }^{2}$ Prof. dr hab., Laboratoire de Développement Rural, Département d'Economie Rurale et Gestion, AGROCAMPUS-Rennes, 65 rue de Saint-Brieuc, CS 84215, F-35042 RENNES CEDEX., Francja, tel./Fax: +33 (0) 2234851 76, e-mail: Christian.Mouchet@agrocampusrennes.fr
} 
podziału pomiędzy członków rodziny) typowo rolniczej (np. w polu), jak i w gospodarstwie domowym oraz ważnych decyzji w zakresie tych dwóch rodzajów działalności. Obserwacja gospodarstw pozwoliła na ustalenie stopnia i typu stosowanej mechanizacji, wielkości plonów, zmian zagospodarowania przestrzeni w ciagu ostatnich lat oraz wykorzystywanych technologii rolniczych.

Niniejszy tekst przedstawia uogólnienia pierwszego etapu badań. Druga część wywiadów ma pozwolić na stworzenie szczegółowych monografii gospodarstw. W drugiej turze wywiadów pytania dotyczyły wyboru i organizacji różnych rodzajów działalności rolniczej, wiedzy i zdolności potrzebnych przy prowadzeniu tej działalności oraz sposobów ich przekazywania, ogólnej organizacji pracy w rodzinie w powiązaniu z czynnikami ekonomicznej równowagi rodziny. Do tych ostatnich włączono produkcję na samozaopatrzenie (żywność, energia), sprzedaż produktów rolnych, zarobki z tytułu pracy poza gospodarstwem i transfery społeczne oraz nieformalną wymianę produktów i usług $\mathrm{z}$ otoczeniem gospodarstwa.

W końcowym etapie planowane są rozszerzenie badań i próba odniesienia wyników do skali ogólnokrajowej, przez przeprowadzenie podobnych wywiadów w innych gminach (Zator w Małopolsce, Drobin na Mazowszu, Stęszew w Wielkopolsce) w $2005 \mathrm{r}$. Wiele socjologicznych i ekonomicznych obserwacji na podobne tematy zostało już zebranych przez IRWIR PAN ${ }^{3}$ w Polsce i przez $\mathrm{CNRS}^{4}$ we Francji.

\section{Społeczne strategie rozwoju gospodarstw ukierunkowanych na samozaopatrzenie}

\section{Obserwacje}

Gospodarstwa badane w 2003 r. reprezentują specyficzny profil rodzinnych gospodarstw rolnych: uzupełnianie się między uprawami polowymi i chowem bydła, konieczność uzyskiwania wpływów finansowych $z$ innych źródeł niż dochody $\mathrm{z}$ gospodarstwa, silna ekonomiczna i praktyczna solidarność pomiędzy dwoma lub trzema pokoleniami w rodzinie.

Minimum biologiczne dochodu zostało oszacowane na 1700 euro na osobę w skali roku. Tak szacuje się na podstawie badań przeprowadzonych w rodzinnych gospodarstwach rolnych o powierzchni 5 hektarów [Bafoil i in. 2003], na

\footnotetext{
${ }^{3}$ Reprezentowany w tej pracy przez prof. dr hab. Marie Halamska.

${ }^{4}$ Centre National des Recherches Scientifiques, reprezentowany w tej pracy przez prof. MarieClaude Maurel.
} 
poziomie cen $2001 \mathrm{r}$. Minimalna suma potrzebna do bieżącego odtwarzania majątku trwałego gospodarstwa rolnego została oszacowana przez cytowanych autorów na 3000 euro na osobę w skali roku. W większych rodzinach, w których w skład wspólnych dochodów wchodzą również emerytury (ze średnią kwotą 1600 euro na osobę w skali roku), młodsi członkowie rodziny moga pracować $\mathrm{w}$ ciagu roku w niepełnym wymiarze czasu pracy poza gospodarstwem i możliwe jest zachowanie pełnego zakresu działalności gospodarstwa, z ogrodem (z którego plony przeznaczone są na samozaopatrzenie), uprawami polowymi i bydłem. W przypadku, gdy taki społeczny transfer nie jest możliwy (brak emerytury lub tylko jedna emerytura), zewnętrzne wpływy są absolutnie niezbędne, aby zapewnić utrzymanie rodzinie i ewentualnie odtworzyć choć część majątku trwałego w gospodarstwie. Dawniej taka dodatkowa, zewnętrzna praca była raczej wykonywana przez mężczyzn. Biorąc pod uwage rosnące bezrobocie w Polsce oraz ewolucję społecznej pozycji kobiety, obserwuje się bardziej oportunistyczne zachowania, jeśli chodzi o kwestię podejmowania dodatkowej pracy. Tym samym wpływ dodatkowego zatrudnienia na organizację produkcji w gospodarstwie jest inny, uzależniony od możliwości mężczyzn i kobiet podjęcia zatrudnienia poza gospodarstwem, co z kolei uwarunkowane jest bardziej przez lokalne i osobiste możliwości niż przez wybór organizacji rodzinnej.

Tradycyjne kobiece zadania $\mathrm{w}$ gospodarstwie, które zazwyczaj mają charakter pracy manualnej, a za cel raczej produkcję i przygotowanie żywności dla rodziny, zaczynają zanikać lub ulegają zmianie w przypadku, gdy kobieta ma dostęp do pracy na zewnątrz gospodarstwa. Konsumpcja produktów samozaopatrzeniowych pochodzących $\mathrm{z}$ ogrodu oraz drobiu zostaje również uproszczona lub zanika. Tradycyjne męskie zajęcia, które są raczej zmechanizowane i nastawione na produkcję towarowa, zostają utrzymane. Jedną z konsekwencji jest utrata samowystarczalności gospodarstwa, jeśli chodzi o żywność. Bardziej nowoczesne gospodarstwa mają wówczas tendencję do podejmowania wyspecjalizowanej produkcji towarowej, na przykład owoców czy warzyw.

W przypadku, gdy mężczyzna pracuje poza gospodarstwem, tradycyjne zadania, które wykonuje w gospodarstwie własnym (cała praca zmechanizowana) stają się coraz bardziej uproszczone. W konsekwencji tradycyjne zmianowania upraw zanikają. W celu skrócenia czasu męskiej pracy w gospodarstwie występuje tendencja do wprowadzenia monokultury zbożowej. Z powodu braku paszy i braku czasu, żeby zajmować się bydłem, zmṇiejsza się również liczba zwierząt. Brakuje również obornika do nawożenia upraw. W tym miejscu warto podkreślić, że z przyczyn ekonomicznych i sanitarnych niektóre mleczarnie przestały przyjmować mleko $\mathrm{z}$ mniejszych gospodarstw. Taka zmiana sytuacji ekonomicznej prowadzi do podobnych do wymienionych wyżej zmian 
W. gospodarstwie, czyli zmniejszenia pogłowia bydła i ilości obornika. W takim przypadku tradycyjne zadania kobiece są utrzymywane, a w gospodarstwie następuje powrót do produkcji przeznaczonej głównie na zaspokojenie własnych potrzeb żywnościowych. Rozwiązania adaptacyjne stosowane przez niektóre rodziny kierowane są na otwieranie sklepów, restauracji w gospodarstwach, prowadzenie usług turystycznych $\mathrm{w}$ gospodarstwie oraz produkcję związanego $\mathrm{z}$ tym rękodzieła (jak pieczenie chleba). Zaangażowanie męskiej siły roboczej poza gospodarstwem może również prowadzić do samoistnego zalesienia terenu użytków rolnych, a produkcja miodu oraz wykorzystywanie innych bogactw leśnych (drewno, żywność pochodząca z runa leśnego) staje się interesującym źródłem dochodu dla takich rodzin.

\section{Refleksje i hipotezy}

Zaobserwowane rozwiązania organizacyjne wynikaja z charakterystycznych socjologicznych cech chłopów, takich jak silna solidarność łącząca dwa lub trzy pokolenia tej samej rodziny, jak również specyficzny sposób podziału zadań w gospodarstwie. Jasno zdefiniowane są zadania męskie i żeńskie, jakiekolwiek byłoby uznanie społeczne dla kobiet pracujących poza gospodarstwem. W części naszych przyszłych badań sprecyzowane zostaną elementy, które determinują historię rodziny i gospodarstwa, jej zależność od dostępu do środków finansowych dostarczanych przez pracę na zewnętrz gospodarstwa, jak również istniejące powiązania pomiędzy działalnością zarobkową każdego członka rodziny a organizacją zadań w gospodarstwie.

Specyfika polskiego rolnictwa, głównie charakteryzowanego przez wielką liczbę małych gospodarstw o wielokierunkowej działalności, jest na ogół przedstawiana jako strukturalne upośledzenie przy porównywaniu $\mathrm{z}$ modelem rolnictwa istniejącym w krajach Europy Zachodniej. Możliwości zbliżenia się polskiego rolnictwa do modelu zachodniego zostały wszechstronnie przestudiowane, szczególnie w okresie przedakcesyjnym. Zarówno hipoteza konwergencji, jak i opór rzeczywistości względem takiego scenariusza zostały jasno opisane $\mathrm{w}$ badaniach zleconych przez Komisje Europejską $\mathrm{i}$ opublikowane przez profesora Alaina Pouliquena [2001].

W obliczu braku profesjonalnych rozwiązań w rolnictwie i zbieżności cen produktów rolnych do cen światowych, co powoduje spadek dochodów gospodarstw rolnych, rodziny rolnicze przyjmują specyficzną strategię, opartą na dywersyfikacji źródeł dochodów i adaptacji produkcji do możliwości rynkowych. Konfrontując nasze własne obserwacje $z$ opublikowanymi niedawno dwiema typologiami polskiego rolnictwa, jedną opracowaną we Francji przez 
profesora François Bafoil [2003] i drug̨̧ opracowaną we współpracy profesor Marii Halamskiej w Polsce oraz profesor Marie-Claude Maurel i profesora $\mathrm{Hu}-$ guessa Lamarche we Francji [Maurel i inni 2003], można postawić hipotezę, że powierzchnia 15 hektarów mogłaby stanowić minimum konieczne w gospodarstwie (wielokierunkowa produkcja $z$ uprawami polowymi $\mathrm{i}$ bydkem), aby zapewnić wystarczające dochody rodziny $z$ jednego źródła. W mniejszych gospodarstwach dominuje logika samozaopatrzenia i uzyskiwania dochodów z różnorodnych źródeł.

\section{Agro-ekologia gospodarstw ukierunkowanych na samozaopatrzenie}

\section{Obserwacje}

Pierwsza obserwacja dotyczy niskiego stopnia użycia środków chemicznych w nawożeniu i do interwencji sanitarnych, tłumaczonego przez niedostatek środków finansowych w gospodarstwie. To powoduje, iż rolnicy nadal stosują bardziej tradycyjne technologie, których agronomiczny i ekologiczny aspekt zasługuje na podkreślenie. Wiele $\mathrm{z}$ tych technologii jest pieczołowicie odkrywanych na nowo i rozwijanych, z racji ekologicznych, na terenach najbardziej intensywnie użytkowanych rolniczo w krajach zachodniej Europy. Dobrymi przykładami takich technologii, które ciągle stosowane są w polskich gospodarstwach, są złożone zmianowania upraw, włączając $w$ to uprawy zachwaszczone, jak również uprawy paszowe ozime jako międzyplony (na przykład lucerna lub viscia sativa) przyczyniające się do użyźniania gleb i dostarczające paszy dla bydła. Dają one równowage pomiędzy produkcją roślinną i zwierzęcą przez własną produkcje pasz dla bydła oraz powszechne użycie obornika do nawożenia upraw polowych i ogrodu. Planem naszych badań objęte są też zagadnienia dotyczące między innymi poprawnego $\mathrm{z}$ punktu widzenia agronomicznego następstwa roślin, prymitywnych odmian roślin uprawnych, technik używanych w celu eliminacji szkodników i chwastów, powiązań między wyposażeniem gospodarstwa w środki trwałe a jakością gleb i ich przygotowaniem, technologii stosowanych w produkcji ogrodniczej i polowej. Praktyki powyższe stanowią przejaw kapitału wiedzy, przystosowanego do warunków naturalnych i klimatycznych, który powinien być zachowany. Co więcej, nawet jeśli część tej wiedzy i zwyczajów może ulec zmianom wskutek trudności ekonomicznych, z którymi borykają się rodziny na wsi, ich istnienie 
reprezentuje jednak formę równowagi pomiędzy rolnictwem i użyciem zasobów naturalnych.

Podkreślone muszą być również niektóre obserwacje dotyczące zagospodarowania przestrzeni na poziomie gospodarstwa. W tradycyjnym typie gospodarstwa można rozróżnić cztery rodzaje użytkowania gruntów: ogród, uprawy polowe, trwałe użytki zielone i lasy. Dzięki istnieniu tych czterech użytków rodzina dąży do uzyskania jak największej samowystarczalności, przez zróżnicowane użycie lokalnych zasobów naturalnych, które drobni rolnicy muszą utrzymywać $w$ niepomniejszonym stanie $z$ przyczyn ekonomicznych $i$ technicznych. Potencjał rozwojowy polskiego rolnictwa w kierunku gospodarki rolno-leśnej wydaje się więc oczywisty. Systemy takiej gospodarki mogą dostarczać korzyści ekonomicznych, ekologicznych i energetycznych [Gąsiorek 2000]. Przeanalizowanie takich możliwości oraz zmierzenie potencjału rozwojowego takich systemów agro-leśnych mieści się w planie naszych badań.

\section{Komentarze i hipotezy}

Ukierunkowany na produktywność model rolnictwa rozpowszechniony w krajach zachodniej Europy staje w obliczu poważnego, kosztownego kryzysu ekologicznego, spowodowanego wysokim użyciem nawozów mineralnych i pestycydów w uprawach polowych, dużą koncentracją produkcji zwierzęcej w niektórych regionach, zubożeniem krajobrazu wiejskiego. Konsekwencjami są między innymi drastyczne zanieczyszczenie rzek i wody pitnej azotem, pestycydami i toksynami zwierzęcymi (czasami stężenie azotanów i pestycydów przekracza dziesięciokrotnie stężenie dozwolone w wodzie wodociąowej), zwiększenie szybkości wiatrów, zanik dzikich gatunków roślin i zwierząt. W Polsce, przynajmniej w regionach, w których dominują małe gospodarstwa rolne, taka ewolucja jeszcze nie nastapiła. Chłopskie gospodarstwa rolnicze przyczyniają się do takiej sytuacji dzięki zgromadzonemu kapitałowi wiedzy i technologii wówczas, gdy nie są zbyt osłabione przez trudne warunki ekonomiczne. Stosowane technologie odpowiadają drugiej części Wspólnej Polityki Rolnej, której celem jest zachęcić finansowo do szerokiej gamy wyborów w rolnictwie przyjaznych środowisku naturalnemu. Biorąc pod uwage jego zdolność do zachowania i dowartościowania zasobów naturalnych przez zróżnicowane zagospodarowanie przestrzeni (uprawy, pastwiska, lasy), ten chłopski typ gospodarki rolniczej spełnia środowiskowe cele Wspólnej Polityki Rolnej i powinien być doceniony, w celu zapobieżenia kryzysowi społecznemu i ekologicznemu. 


\section{Dyskusja}

Opisana organizacja pracy i dochody gospodarstwa chłopskiego wykazują na podobieństwo w stosunku do innych społeczności wiejskich na świecie. W badaniach opublikowanych przez etnologów dotyczących malezyjskich systemów rolniczych pojawia się zdanie, które może streścić także polską sytuację: ekonomiczna reprodukcja $w$ gospodarstwach domowych nie opiera się ani na zarobkach $\mathrm{z}$ pracy najemnej, ani na rolnictwie, ale na kombinacji pracy zarobkowej, produkcji i zbieractwa (takiego jak zbieranie jagód, grzybów) [Djama 1999].

Różnorodność źródeł dochodów połączona z samowystarczalnością żywnościową rodziny gwarantuje względną stabilność gospodarstwa domowego. Zasada samowystarczalności spotyka się z nowoczesną i przychylną analizą ze strony ekonomistów środowiska, wśród nich Nicolae Georgescu-Roegena, w reakcji na ekologiczny kryzys spowodowany przez nadmierną eksploatację naturalnych zasobów i energii w skończonych rozmiarów biosferze. Ekonomiści proponują opracowanie rozsądnych sposobów zużywania tych ograniczonych zasobów energii i dóbr przez rynek. Francuski geograf Bernadette Lizet streściła szorstko tę bardzo współczesną analizę: zdyskredytowane rolnictwo chłopskie reprezentuje z każdym dniem bardziej potrzebną samowystarczalność, jednakże opinia publiczna to ignoruje, zarówno w naszym kraju, jak i na całym świecie [Lizet i de Ravignan 1987].

Biorąc pod uwagę te obserwacje, można traktować polski typ rolnictwa nie jako archaizm, ale jako efektywny, pragmatyczny i oryginalny model, który może być technicznie i finansowo podtrzymywany głównie dzięki pomocy europejskiej. Francuski ekonomista profesor François Bafoil uważa, że gospodarstwa chłopskie opierające swój rozwój na działalności dwuzawodowej bądź na podejmowaniu zajęć uzupełniających mogłyby zainicjować inny typ gospodarki rolnej niż ten, jaki obserwuje się dziś w Unii Europejskiej. Dzięki utrzymaniu tych gospodarstw można by w krótkim okresie czasu ograniczyć migrację ze wsi oraz brak zatrudnienia. Jednakże ich przyszłość jest niepewna i zależy głównie od polityk rolnych, które dziś o nich zapominają [Bafoil i inni 2003 ].

Takie ujęcie przewartościowuje domniemane strukturalne zacofanie polskiego rolnictwa $\mathrm{w}$ świetle jego potencjału innowacyjnego. Interesujące badania, opublikowane w 2003 r. w Eastern European Countryside, analizujące paradygmaty ewolucji $w$ rolnictwie wykazały, iż producenci ukierunkowani na samozaopatrzenie mogą być postrzegani jako mieszkańcy wsi robiący użytek $\mathrm{z}$ dostępnych zasobów $\mathrm{w}$ celu utrzymania swoich gospodarstw domowych 
w obliczu niepewności ekonomicznej w sposób społecznie uznawany i historycznie zakorzeniony. Elastyczność rolnictwa na szeroką skalę odpowiada optymalnemu użyciu istniejących zasobów i strategii przetrwania o niskim ryzyku [Small 2003].

We Francji 22 stowarzyszenia rolników z zachodniej części kraju zbierają się od 1994 r., żeby przedyskutować wstrzymanie intensyfikacji w rolnictwie, doświadczenia i praktyki dotyczące redukcji użycia środków chemicznych oraz ogólnie finansowe koszty w ich gospodarstwach, organizację lokalnego rynku i jakościowe oznakowanie produktów. Jeden z francuskich rolników wspomina: my wszyscy obserwujemy to samo, że przy nastawieniu na zmniejszenie kosztów i zwiększenie naszej samowystarczalności osiągamy lepsze wyniki niż przy stosowaniu praktyk intensywnych [Delage 2004].

Warto podkreślić występującą tutaj zgodność ze stwierdzonym wyżej potencjałem innowacyjnym polskich niewielkich rodzinnych gospodarstw rolniczych. Wspomniane grupy francuskich rolników poświęcają czas i energię na zastanowienie się nad własną tożsamością i nad przyszłością ich gospodarstw w celu zdobycia uznania dla ich użyteczności i nowoczesności. Nie spotyka się takich grup rolników w Polsce, co niekoniecznie znaczy, że nie ma ich wcale. Organizacja, przemyślenia i wymiana potencjału z innymi społecznościami rolniczymi na całym świecie, jak również odbudowa poczucia własnej tożsamości mogą być konieczne dla tych grup społecznych w celu wyjaśnienia, wzmocnienia $i$ wzbogacenia ich historycznego potencjału $w$ ramach rozwoju europejskiego rolnictwa. Taka wymiana, która pojawia się w kontekście zagrożeń ekologicznych i socjoekonomicznych, mogłaby być fascynująca.

\section{Literatura}

BAFOIL F., GUYET R., L'HARIDON L., TARDY V. [2003]: Pologne, profils d'agriculteurs. Le Courrier des Pays de l'Est, nr 1034, ss. 28-45.

DJAMA M. [1999]: Transformations agraires et systèmes ruraux mélanésiens en Grande-Terre de Nouvelle-Calédonie. [W:] Systèmes de culture traditionnels et pratiques paysannes nouvelles en Océanie. JATBA, t. XLI(1).

DELEAGE E. [2004]: Paysans de la parcelle à la planète, socio-anthropologie du réseau agriculture durable. Editions Sylepse, Paryż.

GASIOREK S. [2000]: Korzyści wynikające $\mathrm{z}$ agroforestry, czyli zintegrowanego pastwiskowo-leśnego użytkowania terenu. [W:] Regionalne przemiany strukturalne rolnictwa i obszarớw wiejskich w aspekcie integracji Polski z Unią Europejską. Akademia Rolnicza w Krakowie, Kraków.

LIZET B., RAVIGNAN DE F. [1987]: Comprendre un paysage, guide pratique de recherché. INRA Editions, Paryż. 
MAUREL M.C., HALAMSKA M., LAMARCHE H. [2003]; Le repli paysan, trajectoires de l'après communisme en Pologne. Editions l'Harmattan, Coll. Pays de l'Est.

POULIQUEN A. [2001]: Compétitivité et revenus agricole dans les secteurs agroalimentaires des PECO. Rapport à la Commission Européenne.

SMALL L.A. [2003]: The opportunity of subsistence-style agriculture in Central and Eastern Europe. Eastern European Countryside nr 9, ss. 45-62.

\section{Characteristic Features and Innovative Potential of Family Farms in Poland}

\section{Abstract}

Preliminary interviews concerning 20 farms in the regions of Podlasie and Małopolska were carried in 2003 for a doctorate entitled "Interest and future of Polish peasant-like farming systems in European development models: an ethno-agronomical and socio-economic approach". In farms where less than 15 ha are available complementary incomes are necessary. They can be provided either by social transfers, either by salaried work. A precise repartition of tasks on the farm between specific feminine (manual work and provision of subsistence goods) and masculine (mechanized work and production for sale) tasks, explain different evolutions of production depending on access to outside jobs by each member of the couple. Agronomical organization of the farm was also described, with four parts which can be distinguished in traditional farming systems: family garden, field crops, permanent pastures and private forest, and an ecologically positive impact of agronomical techniques observed.

These family-like farming systems can be considered as innovating in context of the contemporary European debate about ecological and economical choices in agriculture, also represented by other groups of farmers in Europe. In the future this could encourage the autonomy and the reduction of inputs employed in the Polish family-run farms, with their new orientations on the European financial help. 